\title{
Metafizyka w kinie Andrzeja Żuławskiego - interpretacja twórczości \\ w świetle filozofii Arthura Schopenhavera i współczesnych nauk biologicznych
}

Filmy Andrzeja Żuławskiego są dziełami metafizycznymi, przy czym owa metafizyka wypływa z poznania biologicznego życia, co w niniejszej pracy spróbuję pokazać, zaczynając od metafizyki woli Schopenhauera, a kończąc na współczesnej ewolucji i genetyce, do których Żuławski się też odnosi. Filozoficzne konsekwencje myśli Schopenhauera inspirującego się $\mathrm{w}$ znacznej mierze przyrodoznawstwem są identyczne z tymi, jakie wypływają ze współczesnych nauk biologicznych i genetyki - można powiedzieć, że Schopenhauer pisząc o nieśmiertelnej woli na podstawie obserwacji przyrody i współczesnych mu odkryć naukowych, doszedł do podobnych wniosków, do jakich dochodzą dziś naukowcy jak Steve Jones, Darryl Reanney czy Richard Dawkins w oparciu o współczesna, wciąż pogłębianą wiedzę naukową. Wszystko to przedstawiam jednak w kontekście, który mnie tutaj najbardziej interesuję, tj. kina Andrzeja Żuławskiego. Nie powstało dotąd wiele tekstów i książek o twórczości kontrowersyjnego polskiego autora, tym bardziej takich, które próbowałyby całościowo uchwycić jego dzieło. Mam nadzieję, że mój artykuł będzie mógł ożywić dyskusję wokół twórczości reżysera, enfant terrible europejskiego kina, szczególnie w związku z premierą jego najnowszego filmu pt. Kosmos (Cosmos, 2015) nakręconego po piętnastoletniej przerwie.

Schopenhauer przeciwstawia się zachodniemu myśleniu mówiącemu o śmierci po życiu, albo jako o całkowitym unicestwieniu, albo 
o nieśmiertelności „od stóp do głów” ${ }^{\prime 1}$, związanej z pojęciem nieśmiertelnej duszy. Sam filozof wyróżnia buddyzm jako wiedzę o życiu i śmierci, która najbardziej bliska jest jego ujęciu rzeczywistości². Wielu ludzi wciąż "biada" nad tym, że wszystkie istoty powstają drogą narodzin z nicości i umierają na nowo zanurzając się w nicości, a teraźniejszość każdej osoby „będzie niebawem należała do odległej przeszłości”. Schopenhauer odpowiada pytaniem:

(...) czy nie jesteś? Czy nie posiadasz owej cennej teraźniejszości (...) A czy rozumiesz jak wszedłeś w jej posiadanie? Czy znasz drogi, które cię do niej doprowadziły, tak abyś mógł pojąć, że śmierć ci je zagrodzi? Możliwość istnienia twego Ja po zniszczeniu twego ciała jest dla ciebie niepojęta; ale czy może być dla ciebie bardziej niepojęta niż twoje obecne istnienie i sposób, w jaki do niego doszedłeś? Czemu miałbyś wątpić, że tajne drogi, które otworzyły przed tobą tę teraźniejszość, nie otworzą ci także każdej przyszłej? ${ }^{3}$

Śmierć nie jest całkowitą zagładą człowieka ${ }^{4}$, podobnie jak nikt nie przypisuje śmierci najniższym siłom przyrody, np. roślinom czy nawet zwierzętom (bo nie stają się wyodrębnioną świadomością, tożsamością), przyznając im „wieczność i wszechobecność." ${ }^{5}$ Tylko „stany i formy” są tym co przemija, każdorazowa świadomość i tożsamość, principium individuationis, utrudnia zrozumienie tego u człowieka, który uważa, że narodził się jako pierwsza istota na świecie i ostatnia jaka będzie żyła, gdy w rzeczywistości natura traktuje ludzi tak samo jak zwierzęta ${ }^{6}$.

Schopenhauer daje przykład silnego ramienia Odyseusza sprzed tysięcy lat: "ta sama siła”, która wprawiała je w ruch, "tu tak energicznie działa” w tym samym, choć innym ramieniu. „Siła wprawiająca w ruch życie, które już uleciało, była tą sama siła, która czynna jest w życiu kwitnącym obecnie”, gdyż "nasza właściwa istota nie przemija"7. Dlatego przyroda jest tak rozrzutna i obojętna w konstruowaniu milionów kunsztownych organizmów wydanych na pastwę przypadkowej śmierci, ponieważ „wie, iż jeśli zginą, spadną z powrotem na jej łono, gdzie

1 A. Schopenhauer, Świat jako wola i przedstawienie, t. 2, przeł. J. Garewicz, PWN, Warszawa 2009, s. 654.

2 Ibidem, s. 653.

Ibidem, s. 691.

4 Co zdaniem Schopenhauera jest prawie nie do zrozumienia dla większości ludzi. Dzieje się tak, ponieważ „umysł nie ujmuje prawdziwej, ostatecznej istoty rzeczy, lecz tylko ich zjawiska, gdyż (...) jest pierwotnie przeznaczony do podsuwania naszej woli motywów, tj. do służenia jej, kiedy zmierza ona do swych małostkowych celów" (A. Schopenhauer, Świat jako wola i przedstawienie, t. 2, op. cit., s. 671, 676-677).

5 Ibidem, s. 664.

6 Ibidem, s. 668.

7 Ibidem, s. 665. 
są bezpieczne, i dlatego upadek ich jest tylko żartem" ${ }^{\prime \prime}$. Schopenhauer rozważając śmierć zwierząt: żab, psów, owadów zauważa, że mimo to wciąż „w każdej chwili wchodzą w życie” nowe, „odnowione" osobniki, takie same, choć inne niż poprzednie. Ponieważ natura traktuje ludzi tak samo jak zwierzęta ${ }^{10}$, zdaniem filozofa po śmierci ludzie nie będą istnieć wiecznie ze swoją świadomością (zgodnie z dominującym w kulturze katolickim wyobrażeniem) jako jedyne żywe istoty na świecie pośród reszty stworzeń, dla których śmierć jest absolutnym zniszczeniem. Nie jest ona końcem ani dla ludzi, ani dla zwierząt, ani dla całej natury, gdyż w rzeczywistości „koło (...) jako schemat powrotu jest najogólniejszą formą przyrody, powtarzaną wszędzie $(. . .)^{\prime \prime 11}$. Schopenhauer wyobraża sobie świat przyszłości, ludzi żyjących inaczej niż my, „,z innymi obyczajami i w obcych strojach" i pyta: „skąd się wszyscy wezmą? - gdzie są obecnie? - gdzie jest przebogate łono brzemiennej światami nicości, w którym dotąd się kryją owe nadchodzące pokolenia? (...) gdzież miałyby być, jeśli nie tam, gdzie była i będzie zawsze rzeczywistość: w teraźniejszości i jej treści"12. Następnie Schopenhauer przyrównuje człowieka żyjącego w nieświadomości do liścia, który niedługo umrze i spadnie, przerażonego swoim unicestwieniem i nie potrafiącego rozpoznać własnej istoty, , tak żądnej istnienia”. „,Rozpoznaj ją ponownie w ukrytej we wnętrzu, tajemnej sile, która sprawia wzrost drzewa - stale jednej i tej samej we wszystkich pokoleniach liści, nienaruszonej powstawaniem ani przemijaniem"13 - tłumaczy filozof.

W większości filmów Żuławskiego bohaterowie konfrontują się z Nietzscheańskim Ogromem życia („Heraklitejskim obrazem rzeki”, „ogromem obcym człowiekowi, nieprzewidywalnym i niemożliwym do ogarnięcia"14). Także Nietzsche, co widać wyraźnie w Narodzinach tragedii, w których używa jeszcze pojęć Schopenhauera (od których tak po prawdzie nie uciekł nigdy; Safranski zwraca uwagę, że idea wiecznego powrotu ma swoje korzenie $\mathrm{w}$ "dionizyjskim micie o bogu umierającym i stale odradzającym się"15, o którym pisał w zainspirowanych Schopenhauerem Narodzinach tragedii), samemu pisze o „wiecznym życiu jądra

8 Ibidem, s. 668.

9 Ibidem, s. 672. Żuławski w Moliwdzie zwraca uwagę na podobną refleksję Jakuba Franka, który zastanawiał się nad śmiercią zwierząt i podobieństwem do siebie pokoleń, a także zwracał uwagę na odnowę przyrody (A. Żuławski, Moliwda, Towarzystwo Ogród Ksiąg, Warszawa 1994, s. 206).

10 A. Schopenhauer, Świat jako wola i przedstawienie, t. 2, op. cit., s. 679.

11 Ibidem, s. 672.

12 A. Schopenhauer, Świat jako wola i przedstawienie, t. 2, op. cit., s. 673-674.

13 Ibidem, s. 674.

14 Z. Kuderowicz, Posłowie. Uwagi o aktualności Nietzschego, w: R. Safranski, Nietzsche. Biografia Myśli, przeł. D. Stroińska, Czytelnik, Warszawa 2003, s. 435.

15 Idem, s. 257. 
bytowania przy postępującym zanikaniu zjawisk"16. W Narwanej miłości (L'amour braque, 1985) w owym Ogromie - „sferze, w której umierasz i umierając zmartwychwstajesz"17, gubi się Léon, biegnący jak szalony, wymachujący rękami wzdłuż oświetlonych lampami arkad środkiem ulicy niemającej końca - jeden z gangsterów biegnie po niego i przyprowadza go z powrotem. Widzimy jak Léon i Micky wystają z długiego, niekończącego się pociągu z wijącymi się wagonami i krzyczą wprost do kamery, gdy pociąg się do niej zbliża: „Spójrzcie! Czy nie jest ogromny?!". Każdy z nich w symboliczny sposób umiera wchodząc do swojego przedziału na koniec filmu. W ciemnym tunelu metra oświetlonym tylko niekończącymi się, kulistymi lampami na suficie, niczym w nieskończonym kosmosie, wśród gwiazd przeżywa swój trans Anna - zagubiona Sofia, przerażona popadnięciem w materię. Także w Opętaniu (Possession, 1981) przez tunele $\mathrm{w}$ kamienicach przejeżdża na motocyklu Mark aż w końcu wywraca się przed balustradą przy rzece, nie mogąc "przejśćc dalej. W tle widać most: przejście na drugą stronę. Jego życie, horyzont się tu kończa, ale, do czego wrócę, nie istota jego życia.

Rośliny, zwierzęta, owady, ludzie, wszystko to "odnowiło się już po tysiąc razy, a przy tym pozostaje stale te same"18. "Sama nasza istota - kontynuuje Schopenhauer - istnieje nieustannie w teraźniejszości, nietknięta przez upływ czasu i umieranie pokoleń, i kosztuje owoców afirmacji woli życia”"19. Dalej mówi: „Jest tylko jedna teraźniejszość i ta istnieje zawsze; jest to bowiem jedyna forma rzeczywistego istnienia"20. W filmie Na srebrnym Globie (1976-1977, 1987) Aza mówi do Jacka: „Teraz, zawsze jest teraz, teraz, zawsze jest teraz!" - zapętlając się, a film Na srebrnym globie, prócz pokazywania zmieniających się pokoleń na nowej planecie, ukazuje przede wszystkim trzy główne przemiany: Jerzego, Marka i Jacka. Każdy z tych bohaterów zastępuje poprzedniego i pojawia się w momencie jego śmierci. Marek przybywa na planetę, kiedy Jerzy jako Stary Człowiek odchodzi na pustynię wysłać kamery i odejść w spokoju. Jacek przybywa na planetę w momencie, gdy Marek zostaje ukamienowany i umiera na krzyżu. Tak samo jak Szaman i Michał w Szamance (1996), którzy wspólnie mówią swój monolog mimo tysięcy lat różnicy między nimi, połączeni tą samą naturą Szamanki, Marek i Jerzy $\mathrm{w}$ różnych czasach wypowiadają dokładnie te same kwestie, nieświadomi własnego podobieństwa: „Teraz czuję się roztopiony w was, skało,

16 F. Nietzsche, Narodziny tragedii albo Grecy i pesymizm, przeł. B. Baran, Inter Esse, Kraków 1994, s. 70.

17 R. Safranski, Nietzsche, op. cit., s. 186-187. Cyt. za: G. Benn, Werke in vier Bänden herausgegeben von Dieter Wellershoff, Wiesbaden-München 1978.

18 A. Schopenhauer, Świat jako wola i przedstawienie, t. 2, op. cit., s. 675.

19 Ibidem, s. 676.

20 Ibidem, s. 677. 
wodo. Czuję nieczłowieczą waszą przejrzystość, całkowity chłód. Jestem nikim! Zawsze byłem nikim! Nienawidziłem. Pogardzałem pogodzonymi. Teraz ja sam jestem godny pogardy, bo pogodziłem się sam ze sobą". Podobnie kobiety w filmie Na srebrnym globie stają się odbiciem wiecznej kobiecości. Kobieta z wymalowanymi oczami na dłoniach, "ta sama”, jak mówi narrator, pojawia się w plemieniu na Starej Ziemi, w czasie drugiego pokolenia na nowej planecie, potem też jako Ihezal już dużo później, gdy przybywa Marek, zaś Jacek na koniec znów widzi w plemieniu tę samą kobietę z wymalowanymi oczami na dłoniach: „więc nie tę sama, inna, ale wiecznie do siebie podobną" - mówi narrator. „Tylko w naszym spostrzeżeniu, którego formą jest czas (...) teraźniejszość okazuje się odmienna od przeszłości" ${ }^{21}$. W Na srebrnym globie jeden z drugiego niejako zaczyna swoje życie, wyradza się tam gdzie poprzedni umarł, od horyzontu, na którym poległ. Nie ma też ucieczki przed tym samym losem, ani przed śmiercia, która byłaby „łaską”, gdyby rzeczywiście mogła przyjść, co łączy ten film z Szamanką. Kiedy Ihezal w ostatniej części filmu występuje w masce symbolizującej ascezę i wyrzeczenie się ciała i zdradza Marka, zadając mu ostatni cios nożem w plecy, Jacek odsłania jej twarz, i okazuje się, że to Aza, kobieta z Ziemi, aktorka, "zdrajczyni”. Schopenhauer zauważa, że nicość absolutna nie istnieje ${ }^{22}$. Istnieje tylko wieczne teraz, nunc stans, wszystko się zmienia, ale nic się nie zmieniło ${ }^{23}$.

Wielkie oko przyrody, które mnie widzi, jej sens, który mnie dźwiga, ten żywy świat, któremu oddaję i odbijam jak w lustrze to, co mi powierzył i przedstawiał w olśniewającym świetle - on jest źródłem, z którego wypływam i któremu przecież nie mogę ujśćc ${ }^{24}$.

Kiedy Thezal kładzie dłonie z wymalowanymi oczami na twarz Marka, ten krzyczy: „Straszne jest się dostać w ręce Boga Żywego!”25, gdyż „W kimś, kto przyjmuje to spojrzenie przyrody, dochodzi do spotkania rzeki z jej źródłem" ${ }^{26}$, dlatego też kobieta podobna do Thezal z wymalowanymi oczami na dłoniach była także w początkach rozwoju ludzkości na nowej planecie, jeszcze za czasów Starego Człowieka, gdyż wszystko się zmienia, ale istota życia wiecznie trwa. Przejawy woli się zmieniaja, ale wola jako jądro pozostaje ta sama: „Lęk przed śmiercią polega w znacznej mierze na fałszywych pozorach, że Ja teraz znika, a świat pozostaje. Prawdą jest natomiast coś wręcz odwrotnego: świat znika, na-

${ }^{21}$ Ibidem, s. 677.

22 A. Schopenhauer, Świat jako wola i przedstawienie, t. 2, op. cit., s. 678.

23 Ibidem, s. 679.

24 R. Safranski, Nietzsche, op. cit., s. 196.

25 Biblia Tysiaclecia. Pismo Święte Starego i Nowego Testamentu, Pallottinnum, Poznań 2003, Hbr 10, 31.

26 R. Safranski, Nietzsche, op. cit., s. 196. 
tomiast najgłębsze jądro jaźni, nośnik i twórca tego podmiotu, w którego przedstawieniu jedynie istnieje świat - trwa"27.

W Jonaszu chłopiec, który uciekł z tego samego Kremla, do którego zbliża się teraz Maryna z Dymitrem w Borysie Godunowie (1989), gdy "pęka” i „miłość wylewa się z niego, jak mleko”, pyta: „kim jestem? (...) Seks usztywniony przez nią, która będzie - była - jego zgubą. Jak zawsze. Jak wszędzie. Poprzez czasy. (...) ty jesteś Ty. (...) Będzie czekała na ciebie ta sama kobieta, jeszcze piękniejsza. Ona też chce być gwiazdą. Też Strzygą. Też, by jej hołdowali. Gotowa na wszystko. Żądna siebie. Bez bytu, szamocząca się z bytem. Zapamiętaj. Musisz wrócić przez przegub śmierci"28. Jonasz dopełnia Borysa Godunowa:

Gdy schnąc, oddychając spokojniej, gładząc jej wypukłe białe ciało, Dymitr jej (Marynie - mój przyp.) powiedział, że ją widział przedtem, na Kremlu, u Eskimosów, w wielorybie i w Afryce, ona uśmiechnęła się dwoma rzędami mocnych białych zębów, i z jej zmęczonego zadu począł wyśliniać się śliski, bijący w pościel, pachnący łajnem ogon ${ }^{29}$.

Schopenhauer zwraca uwagę na to, że tak jak w dramatach Gozziego, w życiu ludzkim niezależnie od czasu mamy do czynienia $\mathrm{z}$,tą samą historią $\mathrm{w}$ różnych kostiumach" i „nikt nie staje się mądrzejszy (...) Te same osoby działają też $\mathrm{w}$ innej sztuce, a o tym nie wiedzą" ${ }^{30}$. Zdaniem Schopenhauera „wola odgrywa wciąż ten sam spektakl”"31. Patrząc na historię ewolucji Marcin Ryszkiewicz stwierdza, że „na rozlicznych scenach rozgrywane były różne warianty tej samej sztuki ${ }^{32}$. (..) Zmieniali się aktorzy, zmieniało się wykonanie, sztuka jednak pozostawała zasadniczo ta sama." ${ }^{33}$ Sam Żuławski twierdzi, że "wszystko jest wariacją na ten sam temat" ${ }^{34}$, „sens życia i jego przebieg są te same od prapoczątku świata" 35 a "książki są te same, różnią się tylko teraźniejszościami”"36. W filmach Żuławskiego została przedstawiona podobna wizja świata. Michał w Trzeciej części nocy (1971) mówi nagi koło leżącej obok niego

27 A. Schopenhauer, Świat jako wola i przedstawienie, t. 2, op. cit., s. 706.

28 A. Żuławski, Jonasz, Philip Wilson, Warszawa 1993, s. 118.

29 Ibidem, s. 120.

30 R. Safranski, Schopenhauer. Dzikie czasy filozofii. Biografia, przeł. M. Falkowski, Prószyński i S-ka, Warszawa 2008, s. 259.

31 Ibidem, s. 260.

32 M. Ryszkiewicz, Mieszkańcy światów alternatywnych. Historia naturalna rozumu, Wiedza Powszechna, Warszawa 1987, s. 238.

33 Ibidem, s. 138.

34 A. Żuławski, Cnota, Wydawnictwo Książkowe Twój Styl, Warszawa 2005, s. 262.

35 Ibidem, s. 275.

36 Ibidem, s. 278. 
nagiej Marty do swojej zmarłej żony, Heleny ${ }^{37}$, która się mu objawiła: "to wszystko dzieje się w tych samych miejscach, tymi samymi słowami". Zaś Marie w Narwanej miłości mówi w formie bezokolicznikowej (też gdy jest naga w łóżku z Léonem): „spać, umierać, zabijać, kochać się... Te same zmagania..." Ponieważ poprzez biologię życie ludzkie jest powtarzalne i się stale odtwarza, losy ludzkie i dramaty tworzące się wokół tych samych tematów: miłości, śmierci, narodzin itd., nie różnią się między sobą przez pokolenia.

Podobnie według Dawkinsa trudno uwierzyć ludziom, że ewolucja jest faktem, trudno uwierzyć $w$ zmieniające się gatunki na przestrzeni milionów lat, w przodków ewoluujących ludzi, gdyż odkrywamy ewolucję poprzez jej ślady, po milionach lat, jak „detektyw na miejscu zbrodni" ${ }^{38}$. Odnajdujemy tylko szkielety, samo życie było niemal niewidzialne. Także Dawkins powołuje się na Heraklita mówiąc, że wszystko płynie i nie ma nic stałego ${ }^{39}$. Schopenhauer tak pisze o nieśmiertelności naszej istoty: „Na skutek tego mimo tysięcy lat śmierci i rozkładu nic jeszcze nie zginęło" ${ }^{40}$. W Narwanej miłości Léon mówi: „Ptak siada na błocie. Zostawia ślad. Piękniejszy niż lot. Piękniejszy niż życie. Myślę o ojcu, o matce, a szukam w błocie...". Zostają tylko ślady naszych żyć, które odkrywamy (stąd być może w Narwanej... w pewnym momencie Léon, nawiązujący $\mathrm{w}$ swym monologu $\mathrm{w}$ jednej z wcześniejszych scen bezpośrednio do współczesnej ewolucji ${ }^{41}$, stoi koło graffiti, na którym napisany jest rok produkcji filmu - 1984, i spluwa prosto w kamerę). But staje się metaforą fallusa w Narwanej miłości ("godasse" - bucior, np. w scenie, gdy Marie całuje Léona, ten podniecił się, spogląda w dół i mówi: „godasse”, a Marie się śmieje, wcześniej Micky używa tego słowa w kontekście erotycznym, np. gdy mówi o tym, że „wszystkie kobiety są dziwkami"). W ostatniej scenie Micky powiedział Léonowi, żeby zdjął buty, wtedy "nas nie zobaczą", bo nie zostawiając śladów, staną się niewidzialni (także nie przekazując życia dalej, skoro but jest symbolem seksualnym). Lukas Kessling w Kobiecie publicznej (La femme publique, 1984) głosi, że kino jest jedynym sposobem aby nasi zmarli żyli dalej - na pozostawienie śladów po życiu. Wymienia słynne nazwiska aktorów i aktorek, których już nie ma, jako ostatnią osobę wymienia siebie. Głębiej jeszcze pokazuje to film Na srebrnym globie, gdzie Jerzy

37 Marta wygląda tak samo jak zmarła Helena. W obie role wciela się Małgorzata Braunek.

38 R. Dawkins, Najwspanialsze widowisko świata. Świadectwa ewolucji, przeł. P. Szwajcer, CiS, Warszawa 2010, s. 33.

39 Ibidem, s. 39.

40 A. Schopenhauer, Świat jako wola i przedstawienie, t. 2, op. cit., s. 675.

41 Poza tym w filmie jeden z bohaterów pokazuje Léonowi książkę Jacques'a Monoda, Przypadek i konieczność. Monod jest laureatem nagrody Nobla za odkrycie mechanizmów genetycznej kontroli działania komórek. 
znalazł jedyny sens swego życia w „rejestrowaniu wszystkiego”, co się im na nowej planecie przydarzało. Całe wielopokoleniowe zmagania zmontowane przez niego i streszczone w około godzinnym filmie oglądamy przecież po tym, jak już się wydarzyły - oczyma naukowców na Starej Ziemi. Wystrzelone przez Jerzego nagrania zostały zauważone, gdy spadały z nieba przez członków plemienia, którzy dostarczyli je do bazy. Wszystko na „srebrnym globie” już się wydarzyło i oglądamy ,już dalej”, w kolejnym „teraz” naukowców na Ziemi, gdyż „zawsze jest teraz", jak mówi Aza (na Ziemi), mimo śmierci i przemijania.

Podobną świadomość własnego przemijania (ale też nieprzemijalności własnej istoty) ma Lukas Kessling w Kobiecie publicznej, ale mają ją przede wszystkim wszyscy bohaterowie Błękitnej nuty (La note bleue, 1991), których już niejako nie ma, już są historia, wszyscy przyglądają się sobie już z dystansu przez lalki-sobowtóry, które stworzył syn George Sand. W ostatnich scenach filmu wychodzi wielki Diabeł z tunelu, z piekła, wśród buchających płomieni - „autor" całego przedstawienia, jak nazywają go bohaterowie. Siła biologiczna, związana z seksualnością tworzy cały świat dramatycznych losów postaci, będących marionetkami własnych głębinnych, nieświadomych pożądań. „Już jest po sądzie" mówi Michał w Szamance. Genetyk Steve Jones uważa, że idea Sądu Ostatecznego wzięła się stąd, iż za każdym razem, kiedy życie odnawia się poprzez seks i genetyczne rekombinacje, poprzez uaktywnienie się np. szkodliwej mutacji u dziecka, która może je zabić, „wyrok sądu ostatecznego" już zapadł. Z każdym pokoleniem dokonuje się „przesiew ludzkiego ziarna”, są zwycięzcy i przegrani, ci którzy ulegną „potępieniu” i nie przekażą swych genów dalej, i ci, którzy będą „zbawieni" - tu na Ziemi, rozmnażając $\operatorname{się}^{42}$. W Szamance widzimy cierpiące na wodogłowie dzieci żyjące w szpitalu, jedne z ofiar woli życia (obok tłumów biedoty na ulicach Warszawy $)^{43}$ - przekraczających jednostkę sił przyrody, które reprezentuje Szamanka. Życie odnawia się jak ożywczy Duch, Geniusz Rimbaud ${ }^{44}$, który „żegna” poprzednie pokolenia i ludy

42 S. Jones, Bóg, geny I przeznaczenie. Co mamy we krwi?, przeł. M. Lewandowska, PRIMA, Warszawa 1997, s. 39, 82-83.

43 Ludzi machających rękami jak skrzydłami, pragnących uwolnienia z cielesnej powłoki - o gnostycyzmie w kinie Żuławskiego i Szamance piszę w jednym z rozdziałów mej pracy o kinie Andrzeja Żuławskiego.

44 „O płodności ducha i ogromie wszechświata! (...) Jest uczuciem i teraźniejszością (...) jest uczuciem i przyszłością. (...) I pozostaje w naszej pamięci, i wędruje... I kiedy cichnie Adoracja, dzwoni jego obietnica: „Precz te przesądy, te stare ciała, te stadła i lata. To epoka, która idzie na dno. (...) Umiejmy (...) wzywać go i widzieć, i przesyłać, i w przypływach i odpływach śnieżnych pustyń podążać za jego wzrokiem - jego tchnieniem - jego ciałem - jego światłem" (A. Rimbaud, Duch, w: Wiersze, Sezon w piekle, Iluminacje, Listy, red. A. Międzyrzecki, Wydawnictwo Literackie, Kraków 1993, s. 253-255). 
i płynie dalej, potężny i nieskończony. Szamanka kontynuuje swój pochód (sił seksualności i płodności) w ostatniej scenie filmu. Wszystkie postaci na koniec Błękitnej nuty mówią o sobie już z perspektywy historii, o tym, jak zakończyły się ich losy i kto, jak zostanie zapamiętany. Perspektywa ta jest możliwa tylko dlatego, że życie "popłynęło" już dalej, że istnieje już perspektywa "teraz" w przyszłości, gdy ich już nie ma. Bycie nie „ku-śmierci” zmierza, lecz ku życiu, mówi Żuławski ${ }^{45}$.

Motyw schodów zawsze symbolizuje u Żuławskiego przejście z jednego życia $\mathrm{w}$ drugie, zmianę. Nie ma zapewne przypadku $\mathrm{w}$ tym, że pierwotnie motyw schodów pojawił się w kinie Żuławskiego w związ$\mathrm{ku} \mathrm{z}$ pragnieniem nawiązania do sceny śmierci na schodach $\mathrm{w}$ filmie Pokolenie Wajdy ${ }^{46}$ - sam tytuł jest znaczący. Także na koniec Diabła (1972), tyle że po gałęziach Drzewa Życia wspina się krwawiący Jakub (zaś Diabeł, personifikujący w kinie Żuławskiego zasadę zdrady, wiecznego płynięcia i zmiany, który przez cały film mu towarzyszył i z którym Bogiem-Diabłem - niczym jego biblijny imiennik walczył i się zmagał, działa dalej), jak potem w Opętaniu, o czym jeszcze napiszę, po schodach wspina się ranny Mark, nim zastąpi go "dziedzic" („,successor"), czy Szern ${ }^{47}$ niejako wyłaniający się z Marka na krzyżu w Na srebrnym globie (z którym też wcześniej walczył w morzu, a obok nich w wodzie stała Drabina Jakubowa do nieba), jak Jana zastępował Michał w Trzeciej czéści nocy na schodach, czy Ethel Elenę w Kobiecie publicznej, także na schodach, po których dwukrotnie (powtórzenie w zwolnionym tempie w czasie napisów na końcu) biegł też Dymitr i Maryna, wyruszający na wciąż „nowe” wyprawy mające wynieść („nowego”) Samozwańca

45 R. Kim, Żuławski. Ostatnie słowo, Czerwone i Czarne, Warszawa 2011, s. 12.

46 P. Kletowski, P. Marecki, Żuławski. Przewodnik Krytyki Politycznej, Wydawnictwo Krytyki Politycznej, Warszawa 2008, s. 285-286.

47 Szern symbolizuje Boga i seksualność, ale także proces walki ludzkości z własną zwierzęcością. Wojny z nimi stają się także parabolą podboju zwierząt przez ludzi, ich „panowania” nad światem [gdy w rzeczywistości to Szerny mają władzę nad ludźmi, którzy w filmie Na srebrnym globie dosłownie odkrywaja, że „nie są panami we własnym domu": planeta, na której pierwotnie mieszkały inne istoty niż ludzie, w dodatku potworne, inwazja armii Marka na miasto Szernów, gdzie skrzydlate Szerny-Potwory w domach przypominających ludzkie kamienice wyglądają przez okna zza firanek. Późniejsze "ludzkie zoo" w Opętaniu, frustracje Anny w związku z jej wielkomiejską samotnością i zamknięciem w domu, w kręgu domowych obowiązków, problemy seksualne Marka. Ważne tematy i inspiracje u Żuławskiego w Opętaniu: Wilhelm Reich i tłumienie seksualności w człowieku, a także wszystkiego co naturalne $\mathrm{w}$ dzieciach, społeczne i religijne przymusy wnikające $\mathrm{w}$ intymne życie człowieka (scena niemal gwałtu Anny na dziewczynce w szkole baletu, ciągła obserwacja mieszkania przez strażników Muru, zdawanie raportów agentom przez Marka), "uwalnianie z pancerzy" aktorów przez Żuławskiego w czasie przygotowań do zdjęć]. Na koniec Szerny konfrontują ludzi z traumatyczną prawda, iż sami jesteśmy nimi (odkrycie kontyngencji, Szerny jako odbicie ludzkości, tworzące takie same struktury religijne), podobnie jak Potwór w Opętaniu okazał się Markiem. 
na tron. W Błękitnej nucie kolejny raz pojawia się motyw schodów do góry, kolejna Drabina Jakubowa w kinie Żuławskiego. „Po wejściu, walce z aniołem - raj" - woła rzeźbiarz Clésinger, a aniołem (l'ange) jest Solange (jak mówi), którą uwodzi. Dodaje, że Chopin nie jest w stanie schodów przejść, gdyż jego ,ja" stoi mu na przeszkodzie, by chcieć w to "wejść": w seks potwierdzający przejściowość. Stąd cała twórczość Chopina (nieśmiertelność kulturowa jednostki ${ }^{48}$ ) i owe androgyniczne starania jego i George Sand, tęsknota za rozmyciem różnic płciowych. George mówi do Fryderyka: „,ani ja nie stałam się mężczyzną, ani ty kobietą". Podobną metaforą w Narwanej miłości był pociąg i przedziały, gdzie okazało się, że Micky wraz z Léonem byli też jednym, objawili się w tym samym przedziale, jeden w miejscu drugiego („Tat tvam Asi”, „tyś tym jest"49: Hrabia i Jakub w Diable: ,,jesteśmy wymienni"). Pociąg symbolizował ten sam Ogrom życia, który przekracza jednostkę, jaki symbolizują schody, drzewo (nieśmiertelne Drzewo Życia), krzyż czy Drabina Jakubowa ${ }^{50} \mathrm{w}$ kinie Żuławskiego.

Seks, prokreacja, śmierć i zmartwychwstanie, narodziny i cały biologiczny wymiar życia są powtarzalne, są "grane przez ludzkość”. „Ja to wiem, ja to gram. Ja umiem odczuć narodziny i śmierć, prawdę i nieprawdę wszystkiego" - mówi Ihezal, jako kobieta, przez rodzenie, będąca bliższa biologicznemu życiu. Życie może się „odgrywać”, jak Aktor w Na srebrnym globie, który mówi, że będzie mógł odegrać Marka, jeśli ten zginie, jak (stale) pojawiający się nowy Dymitr Samozwaniec w Borysie Godunowie (o czym mówią napisy na koniec filmu, co zgodne jest z historią), odgrywający „Dymitra”, wyruszający na nowy podbój, gdyż każdy może odegrać i wcielić się w każdego - jest to także istotą aktorstwa, które tak bardzo Żuławskiego, jako reżysera, interesuje. Jedna osoba może zastąpić druga, bo nowe pokolenia zastępują i odgrywają odtwarzają i odnawiają biologicznie poprzednie. Niczym w filozofii Schopenhauera: „właściwie istnieje jedna tylko istota; złudzenie wielości (Maja), które bierze się z form zewnętrznego, obiektywnego ujmowania

48 Przeciwstawiona nieśmiertelności „mielącej się biologii”, jak mówił Marek w Na srebrnym..., światu zdrady. Chopin ostatecznie rezygnuje z miłości do Solange, świadomy swojej choroby, a także jej młodości.

49 A. Schopenhauer, Świat jako wola i przedstawienie, t. 2, op. cit., s. 852. Patrz też: Michał i Jan w Trzeciej...

50 Przejście, zmiana w nieśmiertelnym Ogromie być może dokonuje się w kontekście de Chardinowskiej drabiny bytów (duchowego rozwoju pogrążonych w ciemności istot materialnych, "od bestii do anioła” - P. Kletowski, P. Marecki, Żuławski, op. cit., s. 140), lub, jak sugeruje Żuławski w Moliwdzie, ewolucji. „Gdy Frank mówi: wszystkie stworzenia: bydło i ptactwo etc., wszystko pójdzie na wyższy stopień niż dotąd było, czy ten ewolucjonista nie wierzy jak Darwin, czy raczej: jak Teilhard de Chardin?" (A. Żuławski, Moliwda, op. cit., s. 149). Marek w Na srebrnym globie mówi $\mathrm{o}$ „przemianie $\mathrm{z}$ widzialnego $\mathrm{w}$ niewidzialne jakiej dokonujemy...”. 
świata, nie mogło przeniknąć aż do najgłębszej, najprostszej świadomości; dlatego odnajduje ona zawsze jedną tylko istotę ${ }^{\prime \prime 1}$. Życie jest nieśmiertelne, jak mówi Schopenhauer, gdyż:

Za konieczne uzna swe istnienie ten, kto zważy, że aż do chwili obecnej, w której egzystuje, już upłynął czas nieskończony, a więc nastąpiły też niezliczone zmiany, a on mimo to jest (...) Gdyby kiedykolwiek mogło go nie być, to teraz już by go nie było ${ }^{52}$.

Aktor staje się potwierdzeniem zasady, że życie będzie się zawsze, przez odnowienie, odtwarzać i odgrywać i nie ma z niego wyjścia. „Gdyby czas mógł nam przynieść zagładę, dawno by nas już nie było. $\mathrm{Z}$ naszego obecnego istnienia wynika po należytej rozwadze, że istnieć musimy w każdej chwili"53. Dlatego w ostatniej scenie Trzeciej części nocy Michał odkrywa zarówno własną śmiertelność (poprzez zobaczenie swoich zwłok), jak i nieśmiertelność: film kończy się klamra, w której Helena jest jeszcze raz $\mathrm{w}$ domu na wsi, widzimy leżące zwłoki jej, dziecka i matki, przykryte białym prześcieradłem. Helena grana przez Małgorzatę Braunek siedzi przed lustrem i nakłada makijaż na twarz, maluje sobie brwi, jakby była w teatrze na próbie, gdyż jest Aktorka, jak każdy. Mówi znamienne słowa z Apokalipsy: „I w owe dni, ludzie szukać będą śmierci, a nie znajdą jej. I będą chcieli umrzeć, a śmierć od nich ucieknie". Żuławski jest reżyserem metafizycznym, stąd interpretowanie Trzeciej części nocy z perspektywy tylko i wyłącznie psychopatologii byłoby wielkim uproszczeniem.

Andrzej Żuławski zwraca uwagę na to, że rozwój Potwora w Opętaniu "zaczyna się od takiej cieczy spermatycznej i wylewa w metrze" 54 . Jest to owa słynna scena transu, w której Anna wyżywa się i wyzwala z całej niewoli i męskiego poddania, także biologicznej konieczności przyjmowania w siebie męskiego nasienia. Taniec Ethel w Kobiecie publicznej także przeradza się w bunt przeciwko niewolącej konieczności wymogów seksualności, w którym Ethel wygląda jakby przechodziła przez stadia ewolucji, z których próbuje się wyrwać, uwolnić, jakby jej

51 A. Schopenhauer, Świat jako wola i przedstawienie, t. 2, op. cit., s. 456.

52 Ibidem, s. 689.

53 Ibidem, s. 690. „Albowiem to my sami jesteśmy istota, która wchłonęła czas, by wypełnić jego pustkę, i dlatego właśnie wypełnia sobą cały czas, teraźniejszość, przeszłość i przyszłość na równi, i tak samo nie możemy wylecieć z istnienia, jak wylecieć z przestrzeni. (...) Nie do pomyślenia jest, by to, co raz rzeczywiście z całą mocą zaistniało, mogło kiedykolwiek stać się niczym i potem nie istnieć przez czas nieskończony. Stąd wzięła się chrześcijańska nauka o powrocie wszystkich rzeczy, hinduska nauka o stale odnawiającym się stworzeniu świata przez Brahmę i podobne dogmaty filozofii greckiej".

54 P. Kletowski, P. Marecki, Żuławski, op. cit., s. 283. 
idealne ciało wykuwało się w czasie tańca. Momentami, szczególnie podczas drugiej sesji, w czasie której zaczyna krzyczeć, tańczy ruszając się jakby szła przed siebie. Pochód jej jest nieskończony, tak jak muzyka, która gdy wydaje się, że już się kończy, zapętla się i zaczyna od począt$\mathrm{ku}$, a Ethel musi dalej zaczynać taniec od nowa, jakby owemu stawaniu się nie miało być końca, jakby nigdy nie mogła się z niego uwolnić. Ethel krzyczy, w pewnym momencie rzuca swoim ciałem jak koń pociągowy szarpiący głową na wszystkie strony - Ethel jest w samych sidłach kształtującego się w ewolucji przed mężczyznami, między mężczyznami i kobietami (ich oczami) ciała. Organizująca owe sesje starsza kobieta pyta Ethel, co robi z tymi wszystkimi mężczyznami, na co Ethel odpowiada: „przerażam ich”. „Przeszłaś długą drogę" - odpowiada - mogę zobaczyć?" - po czym dotyka jej piersi i płci. Gdy fotograf dostaje ataku serca i symbolizujący członek we wzwodzie podłużny przedmiot podnosi się na skutek upadku mężczyzny, Ethel podchodzi do swej „ofiary" i widzi, że dla niego, dla męskiego spojrzenia na przestrzeni milionów lat nie liczyło się nic więcej, tylko uchwycenie jej części ciała związanych z seksem i rozrodczością: widzimy, że robił zdjęcia tylko jej bioder, piersi, łona.

W filmie Opętanie, gdy Mark dowiaduje się o zdradzie Anny, jest to katastrofą jego całego życia. Jednak z perspektywy Ogromu życia, wiecznej, niekończącej się woli, jego pragnienie zatrzymania się tylko na swojej żonie i rodzinie, jest Mefistofelesowskim powiedzeniem „chwilo, trwaj!". Tego typu wrażliwość przejawia Mark w każdej sytuacji: dla niego Bóg pozostał przy umierającym psie, który podszedł kiedyś pod jego ganek i skonał, wcześniej jęcząc przeraźliwie, „jakby zobaczył coś prawdziwego". Mark widzi potem zwłoki psa płynące strumieniem rzeki (co uprawnia moje nawiązanie do Heraklita, do którego odwoływał się zarówno Nietzsche, Schopenhauer, Dawkins, jak i sam Żuławski). Postać jednego z agentów (lub jego przełożonych? A może osoba, którą miał śledzić? Nie wiadomo tego do końca, choć jest razem z policjantami i agentami tajnych służb) pyta go, „czy to nieekonomicznie marnować siebie na psy? Nawet psy, które kochasz?" Mark odpowiada, że kiedy był mały i pies przyszedł do niego umrzeć, on został tam z nim. Wyrażają te słowa całą postawę Marka także w stosunku do swojej rodziny: jest jej całkowicie wierny i jest ona sensem jego życia. Gdy Anna go zdradza, cała rzeczywistość staje się koszmarem. Wnętrze mieszkania, w którym od początku go widzimy, jest niebieskie. Jedynym przedmiotem ciepłym kolorystycznie, wręcz gorącym względem zimnej całości, jest pomarańczowy telefon, który staje się jego wyłącznym kontaktem ze światem i szansą na odnalezienie Anny. Później Mark spędza trzy tygodnie w hotelu w stanie nieświadomości, depresji. Przeżywa ataki epilepsji, nie wie zupełnie, co się z nim dzieje, znajduje się całkowicie poza czasem. Marka przywiązanie do rodziny, wiara w parę z Anną i dziec- 
ko, które razem maja, jest wszystkim, co ma. Dlatego jest jak Mefistofeles, który „przeczy, protestuje, który przede wszystkim zatrzymuje tok życia i utrudnia stawanie się rzeczy". Toteż jego działania skierowane są „przeciw życiu”. „Zatrzymanie się", jakiego pragnie Mark, jest „zanegowaniem Życia. (...) Zamiast ruchu i Życia stara się narzucić odpoczynek, bezruch, śmierć. Każdy bowiem, kto przestaje się zmieniać i przeobrażać, rozpada się i ginie". W ostatecznym rachunku to zbrodnia przeciw "Zbawieniu", zdaniem Eliadego ${ }^{55}$. Podobnie wartościuje Schelling. Już u Schellinga „chcenie jest prabytem”. Schelling rozróżnia „samowolę" (wolę własną) $\mathrm{i}$ „wolę powszechną":

Z wolą własną pragnącą zamknięcia mamy do czynienia dopiero wtedy, gdy konkretna istota buntuje się (powstaje, mówi Schelling) przeciwko uroszczeniom swego rozwiniętego przeciwieństwa - woli powszechnej; gdy ta wola chce siebie samej przeciwko Całości ${ }^{56}$.

Tyle że w większości filmów Żuławskiego złem jest właśnie świat, który nie dopuszcza do owego zatrzymania i szczęścia. W Trzeciej części nocy życie Michała straciło sens wraz ze śmiercią Heleny i dziecka, nie chciał już żyć dalej, ale odzyskał nadzieję, gdy poznał kobietę, w której zobaczył (chciał widzieć?) Helenę, bo nie chciał pogodzić się z jej śmiercią i żyć dalej bez niej. Jakub w Diable zabijał, ponieważ sam był traktowany jak zmarły (wszyscy myśleli że zginął w czasie swojej misji zabicia króla oddającego się carycy) i gdy się pojawił, zobaczył, że życie „płynie" dalej, bez niego, jego Narzeczona brała właśnie ślub z jego przyjacielem, co było dla niego nie do zniesienia. Piekłem i złem jest wiecznie ruchliwy, tańczący Diabeł, wieczny pęd Szamanki, wieczne, szaleńcze wyprawy po nowe zdobycze, nowe wojny, nowe ekspansje i mordy ${ }^{57}$ (Borys Godunow, Na srebrnym globie). To pragnienie sensu, swego rodzaju zwolnienia, uwolnienia, zatrzymania się, stworzenia swojego własnego świata i rodziny było pragnieniem Marka w świecie pozbawionym sensu i jakiegokolwiek znaczenia, będącym wiecznym płynięciem i przeobrażaniem się wszystkiego.

Podobne pragnienie wyrażał Lucas w filmie Moje noce sa piękniejsze niż wasze dni (Mes nuits sont plus belles que vos jours, 1989). Swietnie „mechanizm przyrody", przeciwko któremu chciał się zbuntować także Lucas, wyraził Nietzsche (zainspirowany w tych słowach Schopenhauerem). Ów mechanizm „w samoświadomości człowieka jawi się jako dążący do celu popęd", którym sami jesteśmy. Utrudnia on nam zrozu-

55 M. Eliade, Mefistofeles i androgyn, przeł. B. Kupis, KW, Warszawa 1994, s. 80.

56 R. Safranski, Zło. Dramat wolności, przeł. I. Kania, Czytelnik, Warszawa 1999, S. 55.

57 Patrz też K. Bernaś, Seksualność w kinie Andrzeja Żuławskiego - między afirmacja a buntem, „Aspekty” 2015, nr 1, (http://aspekty.ikp.uw.edu.pl). 
mienie, że tak naprawdę „nie ten cel chcieliśmy osiągnąć, lecz jedynie siebie samego (...) wskutek zrozumienia, że nie istnieje żaden cel, bo zawsze już jesteśmy u celu. Spełniona chwila nie czeka na nas w przyszłości, lecz jest już zawsze teraz, trzeba ją tylko uchwycić, ucząc się być $\mathrm{w}$ niej całkowicie przytomnym, przytomnym umysłem ${ }^{\prime 58}$. Lucas pragnął być wraz z Blanche, być z nią tu i teraz, na zawsze. Pragnął bycia z nia, bycia obecnym, przytomnym, razem. Stracił język i możność nazywania słowami rzeczy, które odcięły go od przeszłości i przyszłości i zanurzyły w owym Schopenhauerowskim nunc stans. Pragnął być w owym "wiecznym teraz" ze swoją ukochaną. Blanche jednak, mimo tego iż także go kochała (byli ze sobą razem, szczęśliwi jak dzieci) i obiecała zostać z nim, w ostatniej chwili postanowiła odejść od niego na kolejne tournée. $\mathrm{W}$ kontakcie z rozstrojonym, poetyckim umysłem arystokratycznego Lucasa zaczęła mówić pięknym wierszem, gdy wcześniej odzywała się tylko językiem ulicy. Stała się bardziej pewna siebie, charyzmatyczna i dojrzała w czasie swoich hipnotyzujących występów. „Pożarła” jego umysł, podobnie jak Szamanka, która dosłownie zjadła mózg Michała, chcąc mieć jego „moc". Nie mogła zostać z Lucasem i tak już bliskim śmierci. Choć zburzyła w ten sposób sens jego życia i zdradziła miłość do niego, to nie mogła zrezygnować z siebie, ze swego biologicznego sensu, jakim jest dostosowanie swego chcenia do chcenia świata, który jako wola, jest niekończącym się chceniem.

Mark, postrzelony i ranny, wspina się po schodach w Opętaniu. Swoją krwią brudzi koncentrycznie schody, wchodząc coraz wyżej, pozostawiając za sobą wężowy ślad. Na dole pojawia się Anna, która przychodzi z odnowioną wersją Marka. „Jak mnie znalazłaś?” - pyta Mark. „Jak mogłabym nie". Tajemnica losu, połączenia, pary, spotkania:

O wiele lepszym przybliżeniem rzeczywistości jest model rzeki genów (...) Przez kolejne stulecia płynie rwący strumień genów, które stale wirują i zamieniają się miejscami, ograniczone jedynie korytem rzek DNA. Konfiguracje genów zmieniają się w czasie, geny łączą się ze sobą i rozdzielają. (...) Pary molekuł, zanim się spotkały $\mathrm{w}$ takim wirze, były już dobranymi współtowarzyszami, są nimi w okresie wspólnej wędrówki w czasie, będą po rozstaniu ${ }^{59}$.

"Chciałam ci to pokazać. Jest już skończony". Pojawia się odświeżony, nowy Mark, staje koło Anny, która uśmiecha się. Falliczny Potwór, który się w Marka przemienił, seksualny bóg kopulującej z nim ekstatyczki i opętanej Anny, karmiony ofiarami, rozwijał się przez cały film, by się do niego upodobnić. Kobieta, silniej związana biologicznie

58 R. Safranski, Nietzsche, op. cit., s. 124.

59 R. Dawkins, Rzeka genów. Darwinowski obraz życia, przeł. M. Jannasz, CiS, Warszawa 2007, s. 60. 
z własnym dzieckiem ${ }^{60}$, jest bardziej pewna siebie przy nim, czuje z nim większą jedność. Mark zostaje zastąpiony przez następcę, dziedzica (successor z surrealistycznej rozmowy z agentami na początku, która tyczyła się prawdopodobnie stosunku seksualnego ${ }^{61}$ ) - w rozmowie Mark mówił, że wypełnił swoją misję i może zostać zastąpiony przez swojego sukcesora. Być może skoro owi mężczyźni związani są ze strażnikami muru berlińskiego, a poprawna jest interpretacja, że są oni Archontami stojącymi na straży rozmnażania ${ }^{62}$, rozmowa między Markiem a jego przełożonymi mogła tyczyć się zapłodnienia, choć niewątpliwie jest to tak wieloznaczna rozmowa, że bardzo trudno zrozumieć co oznacza. Nawet jeśli jest tylko żartem, tak czy siak zostaje bardzo znaczący motyw "successora”. Mark, przyglądając się Annie oddającej się seksualnie Potworowi, obserwował zarówno zdradę Anny z Heinrichem, jak i własny stosunek seksualny z nią ${ }^{63}$, gdyż Potwór reprezentuje tę samą zasadę zdrady wszystkiego i wszystkich (związaną z seksualnością), jaką personifikował Diabeł w filmie o tym samym tytule, Szujski w Borysie Godunowie, Szern w Na srebrnym globie czy Szamanka ${ }^{64}$. Kiedy Mark wy-

${ }^{60}$ J. Diamond, Dlaczego lubimy seks? Ewolucja ludzkiej seksualności, przeł. M. Ryszkiewicz, CiS, Warszawa 1998, s. 57.

61 Wszystkie słowa w tej rozmowie zdają się tyczyć sytuacji Marka i poprzedniej sceny w łóżku z Anną. Na pytanie czy był "skłonny” ten ktoś, z kim się niby spotkał w parku, Mark odpowiada, że tak, „werbalnie”. Można to traktować jako żart z wczorajszej sceny w łóżku z Anną gdzie widzieliśmy tylko ich przykrą rozmowę. Pytanie o to, czy zauważył „zmęczenie” u tego kogoś, byłoby całkowicie bez sensu, gdyby nie chodziło tutaj o samego Marka, jego fizyczną kondycję, seksualną sprawność. Mark odpowiada jednak, że rozpoznał u owego osobnika: „poprawną ocenę rzeczywistości”. Mark jest świadom swej słabości w sprawach seksualnych, swej niższości względem Heinricha, „bezkonkurencyjnego” względem niego. „Czy to czyni go gorzkim/zgorzkniałym?". Taki właśnie był Mark wobec Anny, bardzo wyniosły wobec jej cierpienia, zupełnie się z nią nie liczący. „Nie, pożądliwym” - odpowiada Mark. (...) „Ale czułeś jego moc?” - pytają jeszcze agenci. Mark od razu wychwytuje: „czy się bałem?”. Zobaczymy potwierdzenie tych słów gdy Mark znajdzie się „oko w oko" z Seksualnością. Niezmiernie interesujące jest zapytanie jednego z „agentów” o to, ile miał z sobą "fiolek", na co Mark odpowiada "dwie" - biorąc pod uwagę surrealistyczną treść rozmowy może chodzić o jądra, gdyż ten wątek i ta rozmowa nie mają żadnego znaczenia dla fabuły i związku z nia, jeśli traktować by je dosłownie, a nie metaforycznie.

62 Pokazuję to w mej pracy o kinie Żuławskiego.

63 Mark mówił synkowi o jego mamie, pieszczotliwe, jako o "naszej mamie”. Z matką symbolizującą śmierć i odrodzenie (pochłonięta przez naturę gdy otwiera się okno i słychać szum liści) mieszka Heinrich. Jung mówi o „micie libido”, którego częściami składowymi są: „pierwotne dwupłciowość, nieśmiertelność (niepodatność na zranienie) zdobywana przez wejście do ciała matki (...), zmartwychwstanie w postaci ptaka-duszy i przywrócenie płodności" (C.G. Jung, Symbole przemiany. Analiza preludium do schizofrenii, przeł. R. Reszke, KR, Warszawa 2012, s. 374).

${ }_{64}$ Także przedstawiam to i rozwijam w jednym z rozdziałów mej pracy o kinie Żuławskiego. Rozwój Potwora z Opętania można traktować jako niepokojące „uzewnętrznienie", metaforę procesu rozwoju embrionalnego. 
ciąga broń w kierunku swego sobowtóra (zaraz postaram się wyjaśnić, dlaczego jest to właśnie sobowtór Marka), strzały policji z dołu i agentów (w tym mężczyzny z różowymi skarpetkami) uniemożliwiają mu wyrządzenie jakiejkolwiek krzywdy. Mało tego, strzały przeszywają także i zabijają Annę, której mogło wydawać się, jako "matce”, że jest bezpieczna, a nie ranią sobowtóra Marka, jakby był przezroczysty. Przygląda się jedynie z pewnym nierozumnym zaciekawieniem temu, co się wydarzyło, ale jakby też nieświadomie, jak niemowlę. Strzelający z dołu policjanci, całkowicie "sprasowani" w ujęciu z góry schodów (widać w zasadzie same główki spoglądające do góry) są upersonifikowanymi genami. „Geny są jedyną struktura, która może poszczycić się nieśmiertelnością (...) Molekuły genów są nieśmiertelne" ${ }^{\prime 65}$ - mówi Darryl Reanney. „Geny są wieczne”"66 - potwierdza Dawkins, który „przedstawia obraz myślenia ewolucyjnego posługując się Heraklitową metaforą czasu jako rzeki, zawsze tej samej, ale wciąż innej" ${ }^{17}$. Desmond Morris mówi, że dla niego, jako zoologa (mówi to oczywiście metaforycznie), „dusza mężczyzny mieści się w jego jądrach, dusza kobiety w jajnikach. Tam bowiem znajduje się to, co jest $\mathrm{w}$ człowieku naprawdę nieśmiertelne geny", i dodaje: "gwarancją genetycznej nieśmiertelności są nasze dzie$\mathrm{ci}^{\prime \prime 68}$. Genetyk Steve Jones stwierdza:

Wiara $\mathrm{w}$ odnowę, zmartwychwstanie, $\mathrm{w}$ takiej czy innej postaci, ciała skalanego śmiercią jest rdzeniem każdej religii. Platon oddzielił esencję dusze (nieśmiertelną) od ciała, (...) teoria Mendla oddzieliła informację genetyczną - nieśmiertelną (...) od ulotnej egzystencji jej nosicielki. (...) Odnowicielska zasada, która zapewnia życiu miliony zmartwychwstań od samego jego zarania ${ }^{69}$.

65 D. Reanney, Śmierć wieczności. Przyszłość ludzkiego umystu, przeł. M. Szelenberg, W. Szelenberg, PWN, Warszawa 1993, s. 78.

${ }_{66}$ R. Dawkins, Samolubny gen, przeł. M. Skoneczny, Prószyński i S-ka, Warszawa 1996, s. 60.

67 S. Jones, Bóg, geny i przeznaczenie, op. cit., s. 283.

68 D. Morris, Zwierze zwane człowiekiem, przeł. Z. Uhrynowska-Hanasz, Prima, Warszawa 1997, s. 156.

69 S. Jones, Bóg, geny i przeznaczenie, op. cit., s. 243. „W Uczcie Platona wieszczka Diotyma zwraca się doSokratesa: «Wcale nie za samym pięknem goni miłość,jak ty myślisz, Sokratesie: za płodzeniem... Bo w zapłodnieniu jest jakiś pierwiastek wiekuisty, Nieśmiertelny, o ile może to być w istotach śmiertelnych... Tą drogą chroni się od zatraty wszystko, co śmiertelne; nie tym sposobem, żeby zawsze i wszędzie było naprawdę jedno i to samo (...) ale dzięki temu, że zawsze to, co się starzeje i odchodzi, zostawia po sobie podobna, inną młodą jednostkę... Gwoli nieśmiertelności taka te latorośle otacza troska i miłość»" (ibidem, s. 245). Żuławski cytuje w Moliwdzie na końcu słowa Tertuliana, będące podsumowaniem, jak pisze sam Żuławski, wszystkiego czym się przez całość książki zajmował: „chcę mówić o tym ptaku, znamieniu Wschodu, słynnym ze swej Jednostkowości, cudownym przez swe potomstwo, który spontanicznie obchodząc swój pogrzeb odnawia się sam, u końca; który jest narodzinami; umierając 
„Innymi słowy, seks jest kluczem do wieczności, pozwala bowiem ciału odrodzić się na nowo i odwraca szkody spowodowane przez czas" $^{\prime \prime 0}$ - pisze dalej Steve Jones. Także słowa Marka, opętanego przez Szerna, potwierdzają że nieśmiertelność związana jest z seksualnością w filmach autora Litego boru: „Obraz jej w ekstazie miłosnej, nabitej na niego, krzyczącej. Mówisz, w środku, dostać się do wewnątrz, wydalić to samo: nieskończoność jest to/do wewnątrz!" Mark i Anna są kolejną parą - ofiara, w kinie Żuławskiego, która umiera w służbie nieśmiertelności, zdradzona ${ }^{71}$ przez własną naturę - nie jest to naprawdę istotne czy pod geny podstawimy gatunek i wolę $\mathrm{w}$ rozumieniu Schopenhauera. W obu przypadkach: „Nie o nas tu chodzi"72. „Idzie o to, że to organizmy istnieją dla DNA, a nie na odwrót"73. Filozofia woli odbija się dalekim echem we współczesnej nauce o genach i ewolucji. Jesteśmy tylko „maszynami genowymi”"74, "kontenerem na geny" ${ }^{\prime 75}$ - tak jak u Schopenhauera jesteśmy "uprzedmiotowioną wolą" (na różnych szczeblach jej rozwoju $)^{76}$, gigantycznym strumieniem woli (współczesna „rzeka genów"177 Dawkinsa). Wola jest ślepym chceniem bez celu i sensu' ${ }^{78}$ (współcześni biolodzy zwracają uwagę na „automatyczność i bezcelowość doboru naturalnego"79), a kontynuacją ${ }^{80} \mathrm{z}$ istoty ",egoistycznej wo-

i sam następując po sobie, stając się znów Feniksem tam, gdzie nie było już nic, stając się znów sam soba, podczas gdy już go nie było, będąc innym, będąc tym samym..." (A. Żuławski, Moliwda, op. cit., s. 274).

70 S. Jones, Bóg, geny i przeznaczenie, op. cit., s. 245. „Dziś (mutacje) uznaje się za immanentną właściwość genów, które zapewniają sobie przeżycie nawet niszcząc gospodarza. Historia mutacji, jak żadne inne zjawisko, jednoczy naukowy i duchowy pogląd na kondycję człowieka. Nadaje idei zmartwychwstania - substancji niezniszczalnej wyrastającej ponad zniszczalne ciało - nowe, precyzyjnie określone znaczenie" [podkreślenie - K. B.] (ibidem, s. 247).

71 Na tylnej okładce powieści Żuławskiego Kikimora znajdują się słowa, które dobrze oddają w zasadzie jeden z głównych tematów twórczości Żuławskiego: „odnawiający się i odnawiany dramat zdrady".

72 R. Safranski, Zło. Dramat wolności, op. cit., s. 73.

73 R. Dawkins, Ślepy zegarmistrz, czyli jak ewolucja dowodzi, że świat nie zostat zaplanowany, przeł. A. Hoffman, PIW, Warszawa 1997, s. 205.

74 R. Dawkins, Rzeka genów, op. cit., s. 24.

75 D. Reanney, Przyszłość ludzkiego umystu, op. cit., s. 90-91.

76 A. Schopenhauer, Świat jako wola i przedstawienie, t. 1, przeł. J. Garewicz, PWN, Warszawa 2009, s. 215.

77 R. Dawkins, Rzeka genów, op. cit., s. 24.

78 A. Schopenhauer, Swiat jako wola i przedstawienie, t. 1, op. cit., s. 266-267.

79 R. Dawkins, Ślepy zegarmistrz..., op. cit., s. 216.

80 Schopenhauer odnosił całą swoją filozofię do najnowszych osiągnięć przyrodoznawstwa i nauk biologicznych przełomu XVIII i XIX wieku. Choć prawdą jest, że Schopenhauer nie rozumiał jeszcze mechanizmów ewolucji, na ogół uważając, że gatunki są stałe (Patrz: A. Schopenhauer, Świat jako wola i przedstawienie, t. 2, op. cit., s. 780, 781), wszak Darwin opublikował O powstawaniu gatunków... rok przed śmiercią Schopenhauera, to jednak w niektórych miejscach Schopenhauer zdaje się intuicyjnie 
li”81 jest współcześnie „samolubny gen”82 Dawkinsa. Z wcześniejszych przykładów widać także, że nieśmiertelne geny w ujęciu wielu ewolucjonistów i genetyków stają się pojęciem metafizycznym podobnie jak nieśmiertelna wola ${ }^{83}$ Schopenhauera.

Wnioski autora Świata jako woli i przedstawienia są identyczne z wnioskami współczesnych genetyków: „nowoczesna genetyka ujawniając powiązania między mutacjami somatycznymi a plazmą zarodkowa, pokazuje, że upadek jednego i odnowa drugiego pozostają w bliskim pokrewieństwie” ${ }^{\prime 84}$. Schopenhauer mówi: „w spojrzeniu kochanków tworzy się już nowa jednostka. Namiętność gwałtowna, cielesna, nowa idea (dziecko) zagarnia w tym celu chciwie materie" ${ }^{85}$. W innym miejscu Steve Jones pisze: „Korzyści wspomagania młodych w przeżyciu dostatecznie długim, by zdążyli przekazać swoje geny, górują nad szkodą (...) - tą mianowicie, że ten sam gen zabija swoich nosicieli, gdy już wydadzą na świat potomstwo ${ }^{86 \prime}$. Zaś Schopenhauer dodaje: „Rozkoszna złuda mami mężczyznę, że w ramionach kobiety, której piękność go pociąga, dozna rozkoszy (...). Tymczasem czyni to tylko dla zachowania właściwego typu gatunku lub po to, by pojawiła się określona jednostka, która pochodzić może tylko od danych rodziców"87. Sam Żuławski cytuje w Niewierności także słowa samego Schopenhauera o „miłości” jawiącej się jako „złowrogi demon"88. W tej samej książce reżyser zdaje się bezpośrednio nawiązywać do Opętania (finałowej sceny na schodach), gdy pisze, że ,jedynym celem naszego pobytu, naszej wspinaczki, naszego spiralnego lezienia po metalowych schodach w górę" jest seks ${ }^{89}$.

Seks, miłość płciowa, zdaniem Schopenhauera: „jest rzeczywiście ważniejsza niż wszelkie inne cele w życiu ludzkim i dlatego w pełni zasługuje na śmiertelną powagę, z jaką każdy do niego dąży. Rozstrzyga się ni mniej, ni więcej tylko skład następnego pokolenia" ${ }^{\prime \prime}$.

Richard Dawkins w Rzece genów pisze identycznie:

(a i na podstawie wiedzy) rozumieć zasadę ewolucji: „Kiedy więc wola życia (...) dążąc bezustannie do uprzedmiotowienia i pełni rozkoszy, przemierzyła wszystkie szeregi zwierząt - przy czym na tej samej planecie zdarzają się nieraz przerwy i szeregi zwierzęce znów rozwijają się sukcesywnie - doszła wreszcie u wyposażonego w rozum człowieka do zastanowienia" (ibidem, s. 810).

81 Ibidem, s. 503.

82 R. Dawkins, Samolubny gen, op. cit., s. 131.

83 A. Schopenhauer, Świat jako wola i przedstawienie, t. 2, op. cit., s. 792-793.

84 S. Jones, Bóg, geny i przeznaczenie, op. cit., s. 249.

85 R. Safranski, Schopenhauer, op. cit., s. 303.

86 S. Jones, Bóg, geny i przeznaczenie, op. cit., s. 249.

87 A. Schopenhauer, Świat jako wola i przedstawienie, t. 2, op. cit., s. 764.

88 A. Żuławski, Niewierność, Baran i Suszczyński, Kraków 2001, s. 415.

89 Ibidem, s. 415. „Biała, okrutna twarz Natury - bez oczu, za to z rozwartymi na otchłań śmierci wargami - kościotrupia twarz, upiorna - Drakula".

90 A. Schopenhauer, Świat jako wola i przedstawienie, t. 2, op. cit., s. 755. 
(...) żywe istoty dziedziczą te geny, które zapewniają powstanie dobrze zaprojektowanej maszyny $\mathrm{w}$ postaci organizmu funkcjonującego tak, jakby dążył do osiągnięcia jedynego, wymarzonego celu - stania się przodkiem $^{91}$.

Łączenie się par to wymóg „,tępej sytości natury, dzięki której jesteśmy w ogóle, i którą czcimy jak węża, co uchwycił własny ogon w paszczę"92 - pisze Żuławski w Piekielnikach. Ceną nieśmiertelności jest jednak śmierć. Oprócz Anny i Marka umierających na schodach przy symbolicznej zmianie, przejściu (z jednego życia $\mathrm{w}$ drugie, przez pokolenia, jak w Na srebrnym globie) jako ofiar seksu i nieśmiertelnych genów/woli jest także para Solange i Clésinger z Błękitnej nuty. Dowiadujemy się na koniec filmu, że Solange miała z nim wiele dzieci, umarła nieszczęśliwa i samotna. Chwilę wcześniej widzimy ich rozczarowanie gdy zmęczeni po miłości fizycznej siedzą w czasie końca świata, u progu końca ich życia. Płonąca w ogniu (anonimowa) para w Kobiecie publicznej (zwłoki niemal zwęglone, kobieta zastygła z rozłożonymi nogami, rękami na łonie; obok nich, na łóżku leżą dwie kule a spośród nich wyrasta zaznaczający się, falliczny kształt), w scenie opętania granej przez Ethel Lizy, także wpisuje się w poczet tych postaci-ofiar. Servais Mont z Najważniejsze to kochać (L'important c'est d'aimer, 1974), pobity w ostatnich scenach i zakrwawiony, leży przy ścianie i podnosi się powoli, niczym potwór w Opętaniu. Servais i Nadine łączą się ze sobą są niewątpliwie ofiarami życia i seksualności, ale takimi, które odnalazły się razem, na dnie, gdzie tylko współczucie, dobroć i wzajemne wsparcie mogą uratować jeszcze świat. Podobnie jak Jan i przypadkowa kobieta na kolei w Trzeciej części nocy. Gdy tylko dochodzi do zbliżenia między nimi zostają natychmiast zabici, szyby zostają rozbite karabinami, a oni zastrzeleni, jakby samo połączenie płci wiązało się już ze śmiercią tych, którzy się połączyli, gdyż w samym spojrzeniu kochanków, jak mówi Schopenhauer, tworzy się już nowa, zastępująca, odnawiająca jednostka ${ }^{93}$. W Nocniku Żuławski nawiązuje do Samolubnego genu (książki wydanej już w 1976 roku) Dawkinsa:

Jesteśmy jeno siedliskiem, ubrankiem, naczyniem i schowkiem dla Mr. i Ms. Gen, którzy nas wybierają chwilowo, sami niezniszczalni podają

91 R. Dawkins, Rzeka genów, op. cit., s. 17.

92 A. Żuławski, Piekielnicy, BGW, Warszawa 1994, s. 26.

93 M. Ryszkiewicz, Mieszkańcy światów alternatywnych, op. cit., s. 34 . U niektórych zwierząt wręcz istnieje "strategia rozwoju totalitarna”, szybkość rozrodu posunięta jest w niej do ostateczności. „U niektórych gatunków larwy przed narodzeniem zawierają już w sobie larwy następnego pokolenia”. Andrzej Żuławski pisze: „Na początku, od zarania, ktoś musi umrzeć, by się narodziło życie: to sens misteriów". (A. Żuławski, Moliwda, op. cit., s. 188). 
sobie pałeczkę płci i przetrwania, mnożenia się i - w końcu - poszukiwanej na oślep nieśmiertelności, gdy już nas, zezwłok, porzuca, wyssanych (stąd tyle filmów o wampirach, trupach wskrzeszonych, mumiach wyżerających treść ofiary, niezbędna, by żyły dalej) $)^{94}$.

To samo pokazywał Żuławski w Trzeciej części nocy przez wszy ${ }^{95} \mathrm{wy}$ sysające z ludzi życie (ostatnie ujęcia, w których Michał widzi w osobnych pomieszczeniach trupy obwiązane klatkami z wszami), czy przez Szerny wyczerpujące ludzi (kobiety) seksualnie - seks, który „zużywa" ludzi, "zdradza” ich, potwierdza ich śmiertelność i przejściowość, o czym mówił Jacek w Na srebrnym globie ${ }^{96}$. Schody są więc metaforą przejścia do nowego życia - tak jak w Opętaniu, gdzie pojawia się „successor" Marka, upostaciowione nieśmiertelne geny. W innych filmach Żuławskiego także pojawia się ",zastępca” na schodach: Ethel zastępująca Elenę w Kobiecie publicznej, Michał zastępujący Jana w Trzeciej części nocy. Też wiąże się to ze zdrada, ale w bardziej potocznym sensie: pojawia się trzecia osoba w związku, „Wąż”, który ostatecznie musi „zatryumfować" w każdym Raju ${ }^{97}$, jak pisze Żuławski. Ludzie jednak zdają się być niewinni wobec własnej, grzesznej natury, którą w sobie odkrywaja, wobec okrutnego świata, którego nie rozumieją (Marek: „świecie,

94 A. Żuławski, Nocnik, Wydawnictwo Krytyki Politycznej, Warszawa 2010, s. 91. Film Na srebrnym globie jest takim przykładem: scena, w której Szerny wychodzą zza grobów w stronę armii Marka (w czasie owego nienaturalnego dźwięku z syntezatora), gdy ludzie weszli do miasta Szernów.

95 „Widzisz, tylko one są ważne. One was utrzymują przy życiu, nie można ich krzywdzić, nie można ich oszukiwać (...)" - mówi do Michała o wszach jego "hodowczyni". "Ja będę pana hodowczynią" - tak przedstawia się w wizji (a może wspomnieniu) Michała Helena, ucząca go, niewinnego i nieznającego życia, jak ma przeżyć. Pokazuje mu też w pewnym momencie wszy powstałe w wyniku „krzyżówki genetycznej" z wszami z Abisynii, które są "lepsze i zdrowsze”. Konotacje seksualne i genetyczne nasuwają się same. „Liczą się geny i informacje, a nie nośnik, czyli osobniki" (S. Jones, Bóg, geny i przeznaczenie, op. cit., s. 16.) Krew, którą piją wszy jest w kulturze symbolem genów, rasy, duszy, osoby etc. - na co zwraca uwagę Steve Jones (ibidem, s. 6). Żuławski często pokazuje wszy w powiększeniu. Widzimy jak w klatkach mrowią się, jedna na drugiej, ślepe, ale organiczne, żywe jak wola Schopenhauera w najczystszej postaci pozbawiona jeszcze zdolności poznawczych. Także i w Trzeciej części nocy Żuławski dotyka poziomu biologicznego życia, a wojna staje się metaforą uniwersalnych, egzystencjalnych konfliktów.

96 „Jesteś znów jedną spośród wielu. Bierzesz udział w przetargu. (...) Nie wiesz jednak, że to nie ty wystawiasz cenę i wartość towarów na tym targowisku, że ręka, która w tobie gmera wynicowując ciebie gruczołami na wierzch, jest ręką samej zasady targowiska, jakby morderczą ręką czy okiem, które znajduje przyjemność w patrzeniu jak zużywają się, jak psy, rządni, merdający, aktorzy". W czasie mówienia tych słów Jacek doprowadza swą ręką Azę do orgazmu.

97 A. Żuławski, Bilet miesięczny, Wydawnictwo Książkowe Twój Styl, Warszawa 2004, s. 41. Temat zdrady pojawia się często w bardzo osobistej literaturze Żuławskiego. 
co uczyniłem, że ciebie nie rozumiem"). W każdym filmie Żuławskiego bohaterowie szukają moralności i sensu, możliwości odkupienia swych przewin, jak np. Michał w Trzeciej części nocy, czy jego siostra, która mogła się uratować, a poszła do obozu wraz ze swoimi podopiecznymi.

Mark był Potworem, ponieważ Mark odkrył własny egoizm w postaci swojego sobowtóra, pragnienia odnowienia i powielenia siebie, a jak mówi Darryl Reanney, ego jest godnym spadkobierca samolubnych genów ${ }^{98}$. To, czego pragnął Mark poprzez związek z Anna, to własna nieśmiertelność. Steve Jones zwraca uwagę, że „choć mężczyźni w największym stopniu przyczyniają się do uszkodzenia komórek płciowych, zadanie ich odnowy spoczywa głównie na kobietach" ${ }^{\prime 99}$. Mark chciał uczynić z Anny matrycę własnej nieśmiertelności, skrycie marzył o tym, by Anna dała mu „magiczną różdżkę”, która mogłaby go odnowić (reinstall), jak mówi w rozmowie telefonicznej Margie ${ }^{100}$, o czym marzyła Anna (impotencja Marka w scenie w łóżku z Anną na początku filmu). "Geny mogą tworzyć nowe struktury na własny obraz i podobieństwo" ${ }^{101}$. Także „w psychice ludzkiej dominuje imperatyw indywidualnego przetrwania w nieskończoność"102 "Geny, gdy tylko jest to możliwe, zwiększają liczbę kopii własnego kodu, w nieskończoność, (...) każdy stara się uwiecznić tylko jeden genetyczny wizerunek: własny"103. Jest to możliwe w rozmnażaniu bezpłciowym (tak też bezpłciowo, w pewnym sensie, rozmnożył się Mark). Według Williama R. Clarka starzenie się i śmierć komórek nie są atrybutami życia na Ziemi, pojawiły się po miliardzie lat od przejścia na płciowe rozmnażanie. Wtedy, około miliarda lat po powstaniu życia, pojawiła się śmierć.

98 D. Reanney, Śmierć wieczności, op. cit., s. 91.

99 S. Jones, Bóg, geny i przeznaczenie, op. cit., s. 272. „Podczas tworzenia się komórek jajowych proces cięcia i łączenia odcinków DNA (zjawisk tak wyraźnych w procesie powstawania nowych kombinacji genów) jest bardziej intensywny niż podczas tworzenia się plemników. (...) Wszystko wskazuje na to, że to samce wyrządzają szkody w przeciętnym genie, a samice je naprawiają. Konwencjonalny obraz kobiety jako źródła zepsucia jest więc nieprawdziwy. W rzeczywistości one uosabiają zmartwychwstanie" (idem, s. 277). Patrz też: M.H. Huet, Living images. Monstrosity and representation, w: "Representations 4" Fall 1983, University of California, s. 73-87. Huet zwraca uwagę, że dawniej myślano, iż kobieta w ciąży może przez swoje myśli wpłynąć na wygląd dziecka: upodobnić go do ojca czy przypadkowego mężczyzny, na którego akurat by spojrzała.

100 Oczywiście możliwe są równocześnie wszelkie inne interpretacje, gdyż Opętanie to film niewątpliwie wieloznaczny. Można także patrzeć na sobowtóry Marka i Anny jako na ich ideały: Marka o opiekuńczej kobiecie i Anny o seksualnym monstrum. W powieści Bóg Żuławski napisał, że „żyjemy wyobrażeniami o sobie wzajemnie" (A. Żuławski, Bóg, Wydawnictwo Książkowe Twój Styl, Warszawa 2006, s. 161).

101 D. Reanney, Śmierć wieczności, op. cit., s. 73.

102 Ibidem, s. 91.

103 Ibidem, s. 86. 
„Reprodukujące się wyłącznie przez podział bakterie mają automatycznie zagwarantowaną nieśmiertelność. Nieśmiertelność innych organizmów zależy od uprawiania seksu”"104. „Jedynie komórki rozrodcze są potencjalnie nieśmiertelne ze wszystkich komórek organizmu"105. Ostatnia rozmowa Sobowtóra z Markiem w Opętaniu i Szerna z Markiem w Na srebrnym globie jest podobna, co pokazuje na jeszcze bliższą więź tych dwóch filmów. Kiedy Marek wisi na krzyżu, pyta Szerna: „z tej ciemności, czy wyjdę kiedykolwiek?” "Jak to boli bracie, nieprawdaż?” - odpowiada Szern Awij. W Opętaniu zaś Sobowtór Marka staje nad nim: „,tak trudno z tym żyć, nieprawdaż, bracie?". I idzie wyżej, do góry. Nieśmiertelne geny płyną dalej ${ }^{106}$ (jak Szern, który symbolizuje seksualność, będącą największym przejawem woli ${ }^{107} \mathrm{u}$ Schopenhauera, jak i genów ${ }^{108}$, wiszący teraz w powietrzu nad ukrzyżowanym Markiem, „przekraczający" go), zostawiając za sobą parę kochanków, swe ofiary, które, jak mówił Jacek w Na srebrnym globie: „zużywają się, jak psy, rządni, merdający, aktorzy". Może sobowtór Marka jest także doskonałym wcieleniem Aktora, biologicznie odgrywającego dalej swe narodziny, śmierć i zmartwychwstanie, tego, który obiecał, że odegra Jerzego i Marka w Na

104 W.R. Clark, Płeć i śmierć, przeł. A. Alichniewicz, PIW, Warszawa 2000, s. 57.

105 Ibidem, s. 66. „Komórki somatyczne - a zatem i przymus ich śmierci - powstały dopiero wówczas, gdy DNA zaczął tworzyć kopie samego siebie do celów innych niż reprodukcyjny. W przypadku istot ludzkich znaczy to, że gdy pewna liczba komórek rozrodczych uzyskała szansę przekazania swojego reprodukcyjnego DNA następnych generacjom, reszta - nasze komórki somatyczne - stała się zbędnym balastem. Takie właśnie jest pochodzenie starzenia się i śmierci" (ibidem, s. 86).

106 Żuławski tak tłumaczy w Bilecie miesięcznym film Opętanie, który innymi słowami, za pomocą innej metaforyki, mówi moim zdaniem, w zasadzie o tym samym, stąd wydaje mi się jeszcze bardziej uprawniona moja interpretacja: „W mądrej Kabale, która jest Biblii komentarzem, za tronem Pana Boga stoi dwuznaczna postać, zwana Księciem Lica. Na imię ma ów Metatron, i nie wiedzieć, czy jest Diabłem, czy Aniołem. To uczciwszy punkt widzenia na boskość, czyli morale, niż miotanie na partnera oskarżeń, nawet gdy człowiek - kobieta czy mężczyzna - czuje się tragicznie poharatanym. Toteż w zakończeniu filmu Opętanie okazuje się, że Diabeł, jakiego obie aktorki, ta z życia i ta z kina, wyrodziły z siebie jako jedna i ta sama, ma twarz, ciało, garnitur i spojrzenie męża, którego porzuciły. Zakochany, zdemolowany mąż widzi Diabła jako samego siebie. Diabeł jest jego sobowtórem, odbiciem lustrzanym. Trzeba było mężowi to zobaczyć, by pojać, że zło a) istnieje naprawdę, b) jest mna, c) czyli Nim, oskarżycielem i prokuratorem sprawy, podczas której zakochany w swej połowicy, swej parze i w sobie bohater nie zauważył, że dla swej żony właśnie był zły. Był Szatanem tłumiącym jej ja. Diabeł, Anioł, Metatron, dwa lica. Bo Diabeł, pozwalający jej na bardzo głośne powiedzenie swojego ja, ja, ja, w końcu ukatrupia wszystko, nawet cień złudnej wolności, a zniszczywszy to, nad czym pracował, czeźnie, by wykonać gdzie indziej, na kim innym, swą obłędną nieustanną pracę.

(A. Żuławski, Bilet miesięczny, op. cit., s. 215).

107 A. Schopenhauer, Świat jako wola i przedstawienie, t. 1, op. cit., s. 500.

108 S. Jones, Bóg, geny i przeznaczenie, op. cit., s. 245. 
srebrnym globie po ich śmierci. Także w Opętaniu Sobowtór pyta się napotkanej kobiety gdy kończą się schody: „czy jest stąd jakieś wyjście?”.

Mały Bob chowa się $\mathrm{w}$ wannie, nurkuje $\mathrm{w}$ wodzie przestraszony przybyciem Marka, sobowtóra. Mark objawił się, kim naprawdę jest, z jakiej wojny przybył: jest Potworem, Diabłem, Zdrajca, Zdobywca, zaprogramowanym do tego genetycznie ${ }^{109}$. Anna, biologicznie zaprogramowana $^{110}$ do spełnienia swej kobiecej roli pragnie wpuścić go, otworzyć mu i nie może tego nie zrobić. Trwa wojna płci, słychać dźwięki wojenne, a Mark, niczym płaz, wije się na drzwiach, palcami macając ich powierzchnie, jak zwierzę (podobnie jak potem Milan w Kobiecie publicznej) ${ }^{111}$. Bob pragnąłby nie dorosnąć, schować się przed wojną płci jego rodzice zeszli w samo jej piekło. Dlatego tak ważne jest zachowanie moralności i staranie się, by pozostać w kręgu dobra: w Trzeciej części nocy, w scenie, w której zatracony kolega Michała opowiada o rozkoszy wszy upitych krwią jak szampanem (które także można traktować jako metaforę genów), Michał odwraca się i nie słucha go, tylko widzi (ducha) swego synka, dziecko w sobie, dla którego pragnie zachować własną dobroć i duszę. Jesteśmy dziećmi, odrodzonym i czystym, nowym światem, który stale jest $\mathrm{w}$ nas ${ }^{112}$. Jest $\mathrm{w}$ nas klucz do dalszego odrodzenia - wiąże się to z odpowiedzialnością za to, co robimy i kim jesteśmy w każdej chwili - czego tak świadomy był Michał w Trzeciej części nocy, pragnący swoim dobrem odkupić świat pogrążony w wojnie: dla Dziecka - dla przyszłości - dla Teraz.

Równowagę i pokój, jakie człowiek może osiągnąć ze swoim życiem, przymierze z nieśmiertelnym Ogromem, zaufanie i wierność symbolizuje końcowa scena w przedostatnim jak dotąd filmie Żuławskiego, pt. Wierność (La fidélité 2000), gdy Clélia nakłada obrączki („pradawny symbol wieczności"113) na gałąź Drzewa Życia. Clève znika w drzewie (na tle drzewa, rozpływając się), umiera i odchodzi łącząc się z nieśmiertelnością nieświadomej natury. „Stawanie się i przemijanie świa-

109 M. Ghiglieri, Ciemna strona człowieka. W poszukiwaniu źródeł męskiej agresji, przeł. A. Nizińska, CiS i WAB, Warszawa 2001, s. 244, 333.

110 M. Ridley, Czerwona królowa. Płeć a ewolucja natury ludzkiej, przeł. J. Bujarski, Rebis, Poznań 2010, s. 266.

111 „O wężu, powiedzmy, że Ewa dała się uwieść Szatanowi, gdy przybrał postać jedyna, której się nie bała, ba, w której jak w lustrze rozpoznawała siebie: płaza zimnokrwistego i pustego jak zło, twórcę i macicę wszelkich rzeczy materialnych"

(A. Żuławski, Jonasz, op. cit., s. 136).

112 „Moja ukochana... Tak będziemy? / Jak strumień wpływający do rzeki / Jak Blanche przebudzona w miłości ze swym kochankiem / Przez przypadek, nie wiedząc gdzie i kiedy / Dopełnią koła, znowu jako dzieci" - mówi na koniec filmu Moje noce sa piękniejsze niż wasze dni boy hotelowy (karzeł), a Lucas i Blanche wchodzą do oceanu, śmiejąc się.

113 D. Reanney, Śmierć wieczności, op. cit., s. 125-135. Reanney mówi o obrączkach w kontekście „pierwotnej, cyklicznej struktury czasu”. 
ta, nieskończona różnorodność form, wszystko, co doświadcza siebie jako indywiduum i próbuje zachować własną indywidualność, znajduje się pod wpływem mai"114 - mówi Schopenhauer. Clélia płacze i prosi Clève'a o wybaczenie, gdyż pozostała po stronie życia (niczym także grana przez Sophie Marceau Blanche z Moich nocy...). Dochowała jednak mu wierności do samego końca (podobnie zachowała w sobie obraz własnych rodziców, ideał małżonków trwających przy sobie na zawsze ${ }^{115}$ ). Po tym jak czuje się już z nim pogodzona, odwraca się i odchodzi, ale to nie znaczy, że nie pozostaje wierna "lepszej świadomości” - temu jednak, co „nie da się urzeczywistnić”, co „unieważnia inne formy rzeczywistości" ${ }^{116}$, bo „wola jest tak bardzo wszystkim, że zrównoważyćją może tylko nic, czyli lepsza świadomość" ${ }^{\prime 117}$. W nicość przemienił się w końcu Clève, którego serce, wrażliwość, kruchość nie wytrzymały zmiennej natury świata, brutalnej wobec jego pragnienia zachowania w sobie dziecka. Już w czasie ich ślubu pojawił się uosabiający zdradę Wąż - helikopter, którym hałaśliwie, zaburzając uroczystość ląduje McRoi opodal ruin kościoła w czasie przysięgi małżeńskiej, a także Némo fotografujący ich. W ostatnim ujęciu filmu widzimy w planie totalnym jadącego na motorze mężczyznę do klasztoru, w którym Clélia czuła potrzebę schować się, uciec na chwilę od życia. Nie jest to odrodzony Clève, choć widzimy parę pięknych, kwitnących kwiatów, którym przygląda się kobieta: wieczną i na swój sposób wierną w swym przemijaniu i odradzaniu się naturę. Przeciwnie, to jego rywal - fotograf Némo, przez którego przeżywał chorobliwą zazdrość o swoją żonę i w końcu umarł. Jednak ta sama siła, która kieruje jego przybyciem, kierowała także zazdrością Clève'a i jego pragnieniem zatrzymania Clélii przy sobie - gdy samemu był żywy. Ten sam nieświadomy pęd, od którego zaczyna się wszelkie przemijające życie (kwiaty, o których mówi, że „mogą być bezwstydne"118 i które fotografuje Clélia, uchwycenie kropel spadających z liści, „chwila tuż przed zwiędnięciem kwiatu”, która jest „prawdziwym pięknem" w kulturze japońskiej, o czym mówił jej McRoi), reprezentują obaj

114 R. Safranski, Schopenhauer, op. cit., s. 227.

115 Także w buncie przeciw McRoi, który jest prawdopodobnie jej ojcem. Woli jednak myśleć o swoim ojcu jako o mężczyźnie życia jej matki, wzruszającym, stepującym tancerzu, którego jej matka kochała (i sama Clélia przez niego wychowana), z którym objawia się jej po swej śmierci.

116 Ibidem, s. 158-159.

117 Ibidem, s. 158.

118 Według Schopenhauera wszelki byt ożywiony jest tą samą wolą. „U człowieka wola wręcz ukrywa wraz ze zdolnością do udawania [prawdę] o naszej prawdziwej istocie”. U zwierząt wola życia jest bardziej naga niż u człowieka, zaś roślina „objawia całą swą istotę na pierwszy rzut oka, z pełną niewinnością. Genitalia, które u wszystkich zwierząt znajdują się w miejscu ukrytym, roślina wystawia na widok, na swym wierzchołku". (A. Schopenhauer, Świat jako wola i przedstawienie, t. 1, op. cit., s. 256). 
mężczyźni, a ona sama rozumie na koniec tożsamość życia w jego różnorodności, przemijaniu i powstawaniu, od których nie ma wyjścia, ale z którymi można się - na wieczność - pogodzićn ${ }^{19}$.

\section{Streszczenie}

\section{Metafizyka w kinie Andrzeja Żuławskiego - interpretacja twórczości w świetle filozofii Arthura Schopenhavera i współczesnych nauk biologicznych}

\section{Stowa kluczowe}

Aktor, Andrzej Żuławski, Arthur Schopenhauer; bunt; boskość; kino w drugiej połowie dwudziestego wieku; Friedrich Nietzsche; nieśmiertelność; seksualność; szaleństwo; śmierć; wola; wolność; zdrada; zło

Filmy Andrzeja Żuławskiego są metafizyczne. Ich metafizyczność opiera się na próbie zrozumienia życia biologicznego i pochodzi z filozoficznej kontemplacji ciała i seksualności.

119 Czego jednak nie mógł zrobić Michał w Trzeciej części nocy i przez co popadł w obłęd, ani Milan w Kobiecie Publicznej, który musiał zginąć. Obaj bohaterowie po śmierci swej żony widzieli w nowo napotkanej kobiecie swą dawną miłość. W Trzeciej czéści nocy obie kobiety grała Małgorzata Braunek, w Kobiecie Publicznej Ethel pofarbowała włosy i próbowała upodobnić się do byłej żony Milana, „odegrać" ją. Być może w rzeczywistości nie mamy tylko do czynienia z jednostką chorobową (Damian Janus w książce Psychopatologia a religia nazywa fetyszem tendencje do postrzegania obiektu seksualnego jako nieśmiertelnego), ale biologicznym aktorstwem, biologiczną powtarzalnością życia. I to właśnie burzy sens życia Michała, którym była Helena i dziecko: to, a nie inne, i ta a nie nowo „darowana” kobieta, jak u Hioba. Michał na koniec popadł w obłęd, co może symbolizować przybycie czterech jeźdźców Apokalipsy (nadejście końca świata), gdyż odkrył brak sensu we własnym życiu po śmierci swej żony i dziecka. Michał przez cały film w związku z gorączką w jakiej się znajdował przez karmienie wszy, widział w nowo poznanej kobiecie Helenę - dopiero pod koniec filmu dochodzi do niego jak ona naprawdę wygląda (nie przypomina w ogóle Heleny, to zupełnie inna kobieta). Film odsłania jednak jeszcze jeden fascynujący motyw. Podział na Helenę i Martę to także podział tej samej kobiety na dwie różne osoby w wyniku zdrady (nawet jeśli nie była to zdrada wyrachowana, a wynikająca z dramatycznych okoliczności: uwięzienie Jana, opieka Michała nad nią i nad dzieckiem). Helena najpierw była z Janem, a potem gdy zdradziła go z Michałem musiała stać się kimś innym, akceptując tę zmianę. Część jej osoby wierząca w wierność, pewien wyższy sens pary musiała umrzeć, a zwyciężyła dwulicowość, adaptacja, zdrada siebie by żyć dalej. Świat, którym rządzą biologiczne popędy i konieczność utrzymania się przy życiu za wszelką cenę („,tak trudno utrzymać się przy życiu” - mówi Michał) więzi bohaterów. Życie w takim świecie okazało się jednak niemożliwe zarówno dla Michała jak i Milana, którzy popadli w obłęd i zginęli. 
Ukazują one spójną i komplementarną wizję świata, dlatego też, w związku z wybranymi przeze mnie tematami, będę interpretował wszystkie jego filmy. W niniejszym artykule zajmę się sytuacją ludzi w filmach Andrzeja Żuławskiego, którzy odkrywają jak w filozofii Schopenhauera, „śmierć i nieśmiertelność własnej istoty". Fundamentalne dla tejże metafizyki staje się ciało, podobnie jak ma to miejsce w filozofii Schopenhauera i współczesnej biologii ewolucyjnej oraz genetyce (Żuławski odnosi się także do nich).

Pragnę także odczytać w nowym świetle filozofię Arthura Schopenhauera w kontekście współczesnych nauk biologicznych. Metafizyczna perspektywa Żuławskiego dotycząca nieśmiertelności jest wciąż obecna wśród współczesnych ewolucjonistów i genetyków („,nieśmiertelny gen”, , molekuły DNA są nieśmiertelne"), mimo że nie zawsze są oni tego świadomi.

Bohaterowie filmów Żuławskiego buntują się przeciwko złu oraz niezrozumiałej tajemnicy odradzającego się i odnawiającego życia (oddziaływania biologii), które czyni ludzki los jednakowym przez wszystkie pokolenia (Na srebrnym globie). Drzewo Życia, schody, Drabina Jakubowa (a nawet pociąg w filmie Limpet Love) stają się metaforą transformacji i zmiany. Ostatecznie, bohaterowie odnajdują seksualność jako źródło i rdzeń egzystencji, klucz do zmartwychwstania (nie osób, lecz egzystencji) oraz nieśmiertelność (Na srebrnym globie, Opętanie).

\section{Summary}

\section{Metaphysics in the cinema of Andrzej Żuławski. Interpretation in the context of the philosophy of Arthur Schopenhaver and the contemporary biological sciences}

\section{Keywords}

Actor; Andrzej Żuławski; Arthur Schopenhauer; rebellion; goodness; cinema in the second half of the twentieth century; Friedrich Nietzsche; immortality; sexuality; madness; death; will; freedom; betrayal; evil

The films of Andrzej Żuławski are metaphysical. Their metaphysics is based on the understanding of the biological life and comes from the philosophical contemplation of the body and sexuality.

They present a coherent, complementary vision of the world, therefore in refer to the themes that I have chosen, I interpret all of his movies. In this article I deal with the situation of the men in Andrzej Żuławski's movies who discover, as in Schopenhauer's philosophy, "death and immortality of their own essence". The body becomes the fundamental of the metaphysics, as it is in the philosophy of Arthur Schopenhauer and the contemporary evolutionary biology and genetics (Żuławski refers to them as well).

I also rediscover the philosophy of Arthur Schopenhauer in the context of the contemporary biological sciences. His metaphysical perspective concerning 
the immortality is still present among the contemporary evolutionists and geneticists ("immortal genes", "molecules of DNA are immortal"), although they are not always aware of it.

The characters in the Żuławski's movies rebel against evil and the incomprehensive mystery of the renewing and regenerating life (biological acting) which makes the human fate alike through the generations (On the silver globe). The Tree of Life, stairs, the Ladder of Jacob (and even train in the Limpet Love) become the metaphor of the transgressing Tremendousness, transformation and change. Eventually the characters find the sexuality as the source and the root of the existence, the key to the resurrection (not of persons but their essence) and immortality (On the silver globe, Possession).

\section{Bibliografia}

Benn G., Werke in vier Bänden herausgegeben von Dieter Wellershoff, Wiesbaden-München 1978.

Bernaś K., Seksualność w kinie Andrzeja Żuławskiego - między afirmacja a buntem, "Aspekty” 2015, nr 1, (http://aspekty.ikp.uw.edu.pl).

Clark W.R., Płeć i śmierć, przeł. A. Alichniewicz, PIW, Warszawa 2000.

Dawkins R., Najwspanialsze widowisko świata. Świadectwa ewolucji, przeł. P. Szwajcer, CiS, Warszawa 2010.

Dawkins R., Rzeka genów. Darwinowski obraz życia, przeł. M. Jannasz, CiS, Warszawa 2007.

Dawkins R., Samolubny gen, przeł. M. Skoneczny, Prószyński i S-ka, Warszawa 1996.

Dawkins R., Ślepy zegarmistrz czyli jak ewolucja dowodzi, że świat nie został zaplanowany, przeł. A. Hoffman, PIW, Warszawa 1997.

Diamond J., Dlaczego lubimy seks? Ewolucja ludzkiej seksualności, przeł. M. Ryszkiewicz, CiS, Warszawa 1998.

Eliade M., Mefistofeles i androgyn, przeł. B. Kupis, KW, Warszawa 1994

Ghiglieri M., Ciemna strona człowieka. W poszukiwaniu źródeł męskiej agresji, przeł. A. Nizińska, CiS i WAB, Warszawa 2001.

Huet M.H., Living images. Monstrosity and representation, w: "Representations 4" Fall 1983, University of California.

Jones S., Bóg, geny I przeznaczenie. Co mamy we krwi?, przeł. M. Lewandowska, PRIMA, Warszawa 1997.

Jung C.G., Symbole przemiany. Analiza preludium do schizofrenii, przeł. R. Reszke, KR, Warszawa 2012.

Kim R., Żuławski. Ostatnie słowo, Czerwone i Czarne, Warszawa 2011.

Kletowski P., Marecki P., Żuławski. Przewodnik Krytyki Politycznej, Wydawnictwo Krytyki Politycznej, Warszawa 2008

Kuderowicz Z., Posłowie. Uwagi o aktualności Nietzschego, w: R. Safranski, Nietzsche. Biografia Myśli, przeł. D. Stroińska, Czytelnik, Warszawa 2003.

Nietzsche F., Narodziny tragedii albo Grecy i pesymizm, przeł. B. Baran, Inter Esse, Kraków 1994. 
Reanney D., Śmierć wieczności. Przyszłość ludzkiego umystu, przeł. M. Szelenberg, W. Szelenberg, PWN, Warszawa 1993.

Ridley M., Czerwona królowa. Płeć a ewolucja natury ludzkiej, przeł. J. Bujarski, Rebis, Poznań 2010.

Rimbaud A., Duch, w: Wiersze, Sezon w piekle, Iluminacje, Listy, red. A. Międzyrzecki, Wydawnictwo Literackie, Kraków 1993.

Ryszkiewicz M., Mieszkańcy światów alternatywnych. Historia naturalna rozumu, Wiedza Powszechna, Warszawa 1987.

Safranski R., Schopenhauer. Dzikie czasy filozofii. Biografia, przeł. M. Falkowski, Prószyński i S-ka, Warszawa 2008.

Safranski R., Zło. Dramat wolności, przeł. I. Kania, Czytelnik, Warszawa 1999

Schopenhauer A., Świat jako wola i przedstawienie, t. 1-2, przeł. J. Garewicz, PWN, Warszawa 2009.

Żuławski A., Bilet miesięczny, Wydawnictwo Książkowe Twój Styl, Warszawa 2004.

Żuławski A., Bóg, Wydawnictwo Książkowe Twój Styl, Warszawa 2006.

Żuławski A., Cnota, Wydawnictwo Książkowe Twój Styl, Warszawa 2005.

Żuławski A., Jonasz, Philip Wilson, Warszawa 1993.

Żuławski A., Moliwda, Towarzystwo Ogród Ksiąg, Warszawa 1994.

Żuławski A., Niewierność, Baran i Suszczyński, Kraków 2001.

Żuławski A., Nocnik, Wydawnictwo Krytyki Politycznej, Warszawa 2010.

Żuławski A., Piekielnicy, BGW, Warszawa 1994. 